\title{
Analisis kerusakan daun dan buah kelapa akibat serangan belalang Sexava
}

\author{
Analysis of damage to leaves and fruits of coconut-palm due to attack \\ of Sexava, the long-horned grasshopper \\ F.X. Wagiman ${ }^{*}$, Meldy L.A. Hosang ${ }^{2}$, Fredy Lala ${ }^{3}$ \\ ${ }^{1}$ Departemen Hama dan Penyakit Tumbuhan, Fakultas Pertanian, Universitas Gadjah Mada \\ Jalan Flora, Bulaksumur, Yogyakarta 55281 \\ ${ }^{2}$ Balai Penelitian Tanaman Palma Manado \\ Jalan Raya Mapanget, Manado 95001 \\ ${ }^{3}$ Balai Pengkajian Teknologi Pertanian Maluku Utara \\ Kompleks Pertanian Kusu, Oba Utara, Kota Tidore Kepulauan, Maluku Utara 91030
}

(diterima Agustus 2018, disetujui November 2019)

\begin{abstract}
ABSTRAK
Belalang Sexava merupakan hama penting kelapa yang merusak daun dan buah. Penelitian analisis kerusakan daun dan buah kelapa akibat diserang oleh belalang Sexava bertujuan untuk mengetahui mekanisme kerusakan. Pengamatan visual in situ dilakukan di Pulau Salibabu, Kabupaten Kepulauan Talaud, Provinsi Sulawesi Utara, sementara analisis jaringan dan analisis kimia pada bakal buah terserang serta pengamatan gejala penyakit sekunder dilakukan di laboratorium. Hasil kajian menunjukkan bahwa proses kerusakan daun dan buah kelapa akibat digigit belalang Sexava terjadi secara mekanik. Gejala fitotoksik akibat gigitan belalang dan gejala penyakit sekunder tidak ditemukan. Jaringan buah yang luka setebal beberapa milimeter tampak mengering dan mati, sementara itu jaringan di dekat luka tampak normal. Kadar gula reduksi, selulosa, dan lignin, antara jaringan bakal buah sehat $(1,22 \%, 2,72 \%, 5,66 \%)$ dan yang terserang $(1,22 \%, 2,85 \%, 4,84 \%)$ relatif sama. Bakal buah terserang rontok, sedangkan buah terserang dari tandan umur lebih dari 3 bulan masih tumbuh dan berkembang sampai tua.
\end{abstract}

Kata kunci: belalang Sexava, kelapa, kerusakan mekanik, Talaud

\begin{abstract}
Sexava, the long-horned grasshopper, is an important pest of the coconut palm that destroys leaves and fruits. Study on analysis of damage to leaves and fruits of coconut palms due to being attacked by Sexava was aimed to determine mechanism of the damage. Visual in situ observations were carried out in Salibabu Island, Talaud Islands Regency, North Sulawesi Province, while histological and chemical analyses of attacked young fruits and observation of symptoms of secondary disease were carried out in the laboratory. The results showed that the process of damage to coconut-palm leaves and fruits due to bitten by the Sexava occurs mechanically. Phytotoxic symptoms due to bites of the long-horned grasshopper and symptoms of secondary disease were not observed. Fruit tissue with a thickness of several millimeters appears to dry out and die while the tissue near the wound appears normal. Reduced sugar levels, cellulose, and lignin, between healthy fruit tissues $(1.22 \%, 2.72 \%, 5.66 \%)$ and those attacked $(1.22 \%, 2.85 \%, 4.84 \%)$ were relatively the same. The attacked young-fruits will fall out while attacked fruits on bunches more than 3 months old still keep to grow and develop until ripe.
\end{abstract}

Key words: coconut palm, mechanical damage, Sexava, Talaud 


\section{PENDAHULUAN}

Kelapa (Cocos nucifera L.) merupakan tanaman serbaguna, sumber gizi dan obat-obatan, sumber pendapatan penting bagi jutaan penduduk di daerah tropika dan subtropika. Nilai gizi buah kelapa dan aneka manfaat untuk kesehatan telah diulas oleh DebMandal \& Mandal (2011). Air kelapa sebagai minuman segar sangat baik untuk kesehatan dan sebagai suplemen pertumbuhan dalam kultur jaringan tanaman (Yong et al. 2009). Kendala budi daya kelapa antara lain adanya serangan belalang hama yang merusak daun dan buah.

Salah satu jenis belalang hama pada tanaman kelapa adalah belalang Sexava spp. Tiga spesies belalang tersebut terdapat di Indonesia dengan nama lokal sesuai sebarannya, yakni belalang ambon (Sexava coriacea Linnaeus), belalang talaud atau boto-boto (Sexava nubila Stal.), belalang togean atau kuwao atau tupako (Sexava karnyi Leefmans). Satu spesies terdapat di Papua Nugini, yakni Sexava novaeguineae Brancsik. Belalang ambon tersebar di Dumagin, Sangihe, Halmahera Barat, Sula, dan Banggai. Belalang talaud atau boto-boto, tersebar di Kepulauan Talaud, Seram, Kei, Aru, Bacan, Kepulauan Nanusa, Papua, dan Papua Nugini. Belalang togean atau kuwao (Togean di Teluk Tomini) atau tupako (Ampana), tersebar di Togean dan Kepulauan Una-una, daerah Poh Pesisir Pantai Sulawesi Tengah (1953), serta daerah antara Ampana dan Poso (1948) (Warouw 1981). Selain menyerang kelapa, belalang Sexava dilaporkan menyerang kelapa sawit (Caudwell \& Orrell 1997; Alouw \& Hosang 2016).

Serangan belalang Sexava pada kelapa menyebabkan dua tipe kerusakan. Pertama, serangan langsung pada buah. Bakal buah terserang ringan masih dapat tumbuh dan berkembang sampai tua, sedangkan bakal buah terserang berat akan rontok prematur. Kedua, defoliasi pada pelepah daun secara tidak langsung menyebabkan kehilangan hasil. Serangan pada tanaman belum menghasilkan menyebabkan pertumbuhan tanaman terhambat. Pada beberapa kasus serangan sangat berat terus-menerus menyebabkan tanaman mati (Zelazny \& Hosang 1988). Dampak ekonomi serangan hama Sexava pada tanaman kelapa sangat signifikan. Sebagai contoh, Dinas Perkebunan Provinsi Sulawesi Utara (2008) melaporkan luas serangan dan kehilangan hasil. Pada tahun 2008 luas serangan hama Sexava spp. pada perkebunan kelapa di Kabupaten Kepulauan Talaud, Sangihe dan Siau, serta Bolaang Mongondow mencapai sekitar 16.072,25 ha dan diperkirakan menyebabkan kehilangan hasil kopra sebesar $5.992 .812 \mathrm{~kg} /$ tahun senilai Rp 26.359.602.600,-/tahun. Siahaya (2014) melaporkan intensitas kerusakan kelapa akibat serangan S. nublia di daerah Seram Barat sekitar 5,58\% termasuk kategori ringan. Luas serangan di daerah tersebut pada tahun 2010 sekitar 124,5 ha dan pada tahun 2011 meningkat mencapai 792,79 ha.

Gejala serangan hama belalang Sexava pada kelapa dapat dilihat pada daun dan buah. Anak daun kelapa yang diserang mulai dari pelepah tua. Lembaran anak daun kelapa yang dimakan dengan menyisakan lidi sehingga pelepah-pelepah daun tampak meranggas (Hosang 2005). Buah yang diserang sejak bakal buah sampai buah tua. Bakal buah (bluluk; Jawa) tampak luka di bagian pangkal buah, ada buah yang hampir habis dimakan. Buah sangat muda (cengkir; Jawa) pada bagian sabut di dekat pangkal buah tampak luka dangkal sampai dalam hingga di bagian tempurung. Buah muda (degan; Jawa) dan buah tua pada bagian sabut di tengah-tengah buah tampak luka dangkal sampai dalam (Wagiman et al. 2012).

Fenomena adanya pohon kelapa mati akibat diserang oleh hama Sexava tidak separah jika dibandingkan dengan akibat diserang oleh hama kutu Aspidiotus destructor rigidus Reyne, seperti yang terjadi di Ende, Flores, tahun 2002 (Wagiman 2006). Kutu Aspidiotus bertipe alat mulut menusuk-menghisap, bersamaan dengan pada saat menghisap cairan tanaman kutu tersebut diduga memasukkan saliva yang bersifat fitotoksik ke dalam jaringan tanaman. Belalang Sexava bertipe alat mulut menggigit-mengunyah. Anatomi alat mulut menggigit-mengunyah tidak dijumpai adanya saluran saliva, seperti yang dijumpai pada alat mulut menusuk-menghisap. Oleh karena itu, serangan belalang Sexava pada kelapa dianalisis untuk mengetahui mekanisme terjadinya kerusakan. 


\section{BAHAN DAN METODE}

\section{Lokasi penelitian}

Penelitian lapangan dilakukan pada perkebunan kelapa rakyat di Pulau Salibabu, Kabupaten Kepulauan Talaud, Provinsi Sulawesi Utara. Di pulau tersebut pohon-pohon kelapa mengalami serangan kronis dan endemis hama Sexava sepanjang tahun. Penelitian laboratorium dilakukan di (1) Laboratorium Struktur dan Perkembangan Tumbuhan, Fakultas Biologi, Universitas Gadjah Mada; (2) Laboratorium Kimia PAU, Universitas Gadjah Mada; dan (3) Laboratorium Hama dan Penyakit, Balai Penelitian Kelapa dan Palma Lain Manado.

\section{Pengamatan in situ}

Analisis kerusakan daun dimaksudkan untuk mengetahui mekanisme kerusakan daun. Pengamatan in situ secara visual terhadap kanopi kelapa dilakukan dengan melihat langsung dan dengan memotret kanopi yang sehat dan kanopi yang terserang berat. Kondisi kerimbunan kanopi terserang berat dibandingkan dengan kerimbunan kanopi sehat. Intensitas kerusakan berat ditaksasi dengan skor 4 bila kehilangan daun $75 \%$ lebih (Wagiman et al. 2012).

Analisis kerusakan buah dimaksudkan untuk mengetahui mekanisme kerusakan buah, yakni apakah buah mengalami kerusakan secara mekanik saja atau juga kerusakan secara fitotoksik, serta adanya komplikasi penyakit sekunder. Sampel bakal buah kelapa (bluluk; Jawa) sehat dan terserang diambil dari daerah Kecamatan Moronge dan Lirung, Pulau Salibabu. Tandan buah berikut buah yang rusak diturunkan dari pohon kelapa, kemudian buah-buah yang rusak diamati dengan seksama untuk mengetahui mekanisme terjadinya kerusakan. Buah-buah kelapa yang jatuh juga dikumpulkan dan diamati. Pengamatan visual dilakukan in situ dengan melihat langsung dan memotret tanda serangan belalang Sexava pada buah kelapa.

\section{Pengamatan di laboratorium}

Bakal buah (bluluk) segar yang sehat dan luka terserang belalang dianalisis di Laboratorium Struktur dan Perkembangan Tumbuhan, Fakultas Biologi, Universitas Gadjah Mada. Analisis kerusakan buah meliputi analisis jaringan, kimia, dan patogen sekunder.

Analisis jaringan buah. Protokol pembuatan preparat penampang jaringan bluluk yang sehat dan yang terserang sebagai berikut. Pada hari pertama dilakukan pengirisan bluluk, fiksasi, dan pewarnaan irisan. Bluluk diiris membujur menggunakan alat sliding microtome dengan ketebalan 20-30 $\mu \mathrm{m}$ (mikronmeter). Irisan-irisan tersebut ditampung dalam cawan petri yang diberi alkohol 70\% untuk fiksasi. Selanjutnya pewarnaan dilakukan dengan Safranin 1\% dalam alkohol 70\% selama 24 jam. Penyiapan preparat dilanjutkan pada hari kedua. Safranin dibuang lalu diganti berturut-turut dengan alkohol $70 \%$ selama 10 menit, alkohol 80\% selama 10 menit, alkohol 95\% selama 10 menit, Fastgreen 1\% dalam alkohol 95\% selama 1 menit, alkohol 95\% selama 5 menit, alkohol $100 \%$ selama 10 menit, alkohol:xilol 3:1 selama 10 menit, dan xilol selama 10 menit. Irisan diatur di atas gelas benda, diberi balsam kanada, kemudian ditutup dengan gelas penutup. Preparat dikeringkan di atas hot plate pada suhu $45^{\circ} \mathrm{C}$ hingga balsam kanada kering. Pada sisi sebelah kiri gelas penutup dilekatkan kertas label dan diberi keterangan nama preparat. Preparat kemudian diamati di bawah mikroskop dengan perbesaran 100x. Pengamatan jaringan sehat dan rusak dilakukan dengan membandingkan foto mikroskopi.

Analisis kimia bluluk. Analisis kimia ini dilakukan di Laboratorium Kimia PAU, Universitas Gadjah Mada. Metode titrasi diaplikasikan dalam analisis ini untuk mengukur kadar gula reduksi, selulosa, dan lignin. Kadar ketiganya antara bluluk luka dan sehat dibandingkan.

Analisis patogen sekunder. Kerusakan bluluk terserang belalang Sexava diduga diperparah oleh adanya penyakit sekunder. Dalam penelitian ini luka akibat gigitan belalang Sexava dianggap sebagai penyakit primer. Patogen tertentu terutama cendawan dan bakteri diduga menginfeksi jaringan luka tersebut dan menyebabkan penyakit sekunder. Isolasi cendawan dan bakteri dari jaringan bluluk yang luka dilakukan di Laboratorium Hama dan Penyakit, Balai Penelitian Kelapa dan Palma Lain 
Manado. Status patogen atau nonpatogen isolat tersebut ditentukan dengan konfirmasi hasil telaah referensi.

\section{HASIL}

\section{Profil pertanaman kelapa dan belalang Sexava}

Kebun kelapa di pulau Salibabu merupakan kelapa rakyat. Jarak tanam dan umur tanaman bervariasi. Kelapa umumnya ditanam dengan jarak tidak teratur dan di beberapa lokasi ada yang teratur. Pada umumnya tanaman kelapa sudah berproduksi dan sebagian masih tanaman muda. Serangan belalang Sexava merata di seluruh pulau dengan intensitas kerusakan bervariasi dari ringan sampai berat. Nimfa dan imago belalang Sexava (Gambar 1) aktif merusak tanaman kelapa pada bagian daun dan buah.

\section{Hasil analisis kerusakan daun}

Apabila kanopi kelapa yang terserang berat oleh belalang Sexava dibandingkan dengan yang sehat, perbedaan yang jelas terlihat adalah hilangnya lembaran daun (Gambar 2). Pengamatan visual dari dekat menunjukkan bahwa bekas gigitan belalang pada lembar anak daun tampak robek-robek, tepi daun yang luka lebih kurang $1 \mathrm{~mm}$ berwarna coklat dan mengering. Sisa lembaran anak daun yang tidak dimakan tampak sehat sama dengan anak-anak daun yang tidak dimakan belalang.

Belalang Sexava memakan daun mulai dari tepi lembaran daun pada setiap anak daun sampai di dekat lidi. Jaringan daun bekas gigitan lamakelamaan mengering. Perbedaan warna dan kesegaran yang tegas antara bagian daun yang luka $(<1 \mathrm{~mm})$ dan lembaran daun sisa dimakan mengindikasikan bahwa kerusakan daun ini terjadi secara mekanik.

\section{Hasil analisis kerusakan buah}

Belalang Sexava memakan semua tingkat perkembangan buah kelapa, sejak bakal buah (bluluk; Jawa) (Gambar 3), buah sangat muda (cengkir; Jawa) (Gambar 3), kelapa muda (degan; Jawa) (Gambar 4), dan buah tua (Gambar 5). Pengamatan visual kerusakan bakal buah dan buah kelapa akibat serangan belalang Sexava menunjukkan kerusakan mekanik. Kerusakan ringan hingga berat terjadi pada bakal buah (bluluk). Bluluk dari tandan umur kurang dari 4 bulan masih rentan rontok fisiologis dan dengan adanya serangan belalang ini jumlah buah rontok meningkat.

Hasil analisis jaringan buah. Kerusakan mekanik pada buah tampak jelas diindikasikan oleh perbedaan tegas antara kulit kelapa yang luka dan sehat. Gambar close up kulit kelapa rusak (Gambar 5) menunjukkan respons kelapa terhadap serangan belalang Sexava. Jaringan mati pada kulit luka baru dan luka lama menunjukkan bahwa jaringan mati tampak tidak meluas karena sebab lain. Pada luka lama tampak adanya getah yang mengeras, diduga merupakan lapisan pelindung jaringan sehat.

Proses kerusakan bluluk dapat dilihat pada hasil pengamatan mikroskopis jaringan bluluk. Jaringan bluluk yang rusak dan yang sehat diilustrasikan pada Gambar 6. Jaringan yang diambil dari ujung bluluk luka terserang belalang Sexava, menunjukkan adanya sel-sel parenkim yang mati dan normal serta penebalan berkas pengangkut.

Hasil analisis kimia. Sampel bluluk terserang belalang Sexava dan sehat berasal dari tandan yang sama (Gambar 3). Hasil analisis kimia menunjukkan bahwa serangan belalang Sexava tidak berpengaruh $(\mathrm{P}>0,05)$ terhadap kadar kimia buah. Kadar gula reduksi pada bluluk sehat dan terserang 1,22\%. Rerata kadar selulosa pada bluluk terserang 2,85\% dan bluluk sehat 2,72\%. Kadar lignin pada bluluk terserang 5,66\% dan bluluk sehat 4,84\% (Tabel 1).

Hasil analisis penyakit sekunder. Bluluk dari tandan yang baru diturunkan dari pohon ada yang luka baru dan ada yang luka lama karena digigit belalang Sexava, serta tidak menunjukkan busuk atau bercendawan. Bluluk luka yang sudah lama jatuh di tanah (Gambar 3) tampak membusuk dan bercendawan. Sampel bluluk luka yang dibawa ke laboratorium untuk diisolasi menunjukkan bahwa kemungkinan adanya bakteri atau cendawan yang patogenik. Isolat yang diperoleh sebanyak satu isolat bakteri dan satu isolat cendawan. Status 

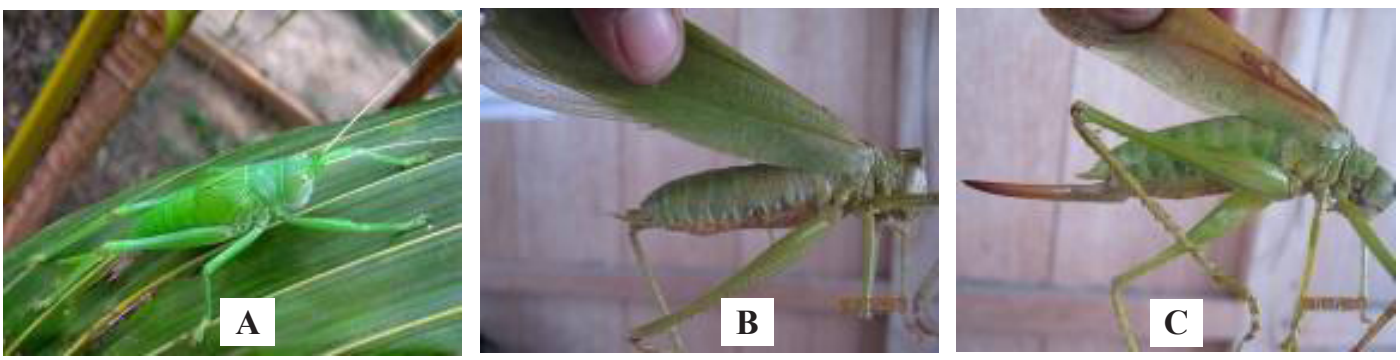

Gambar 1. Nimfa dan imago belalang Sexava. A: nimfa; B: imago jantan; C: Imago betina.

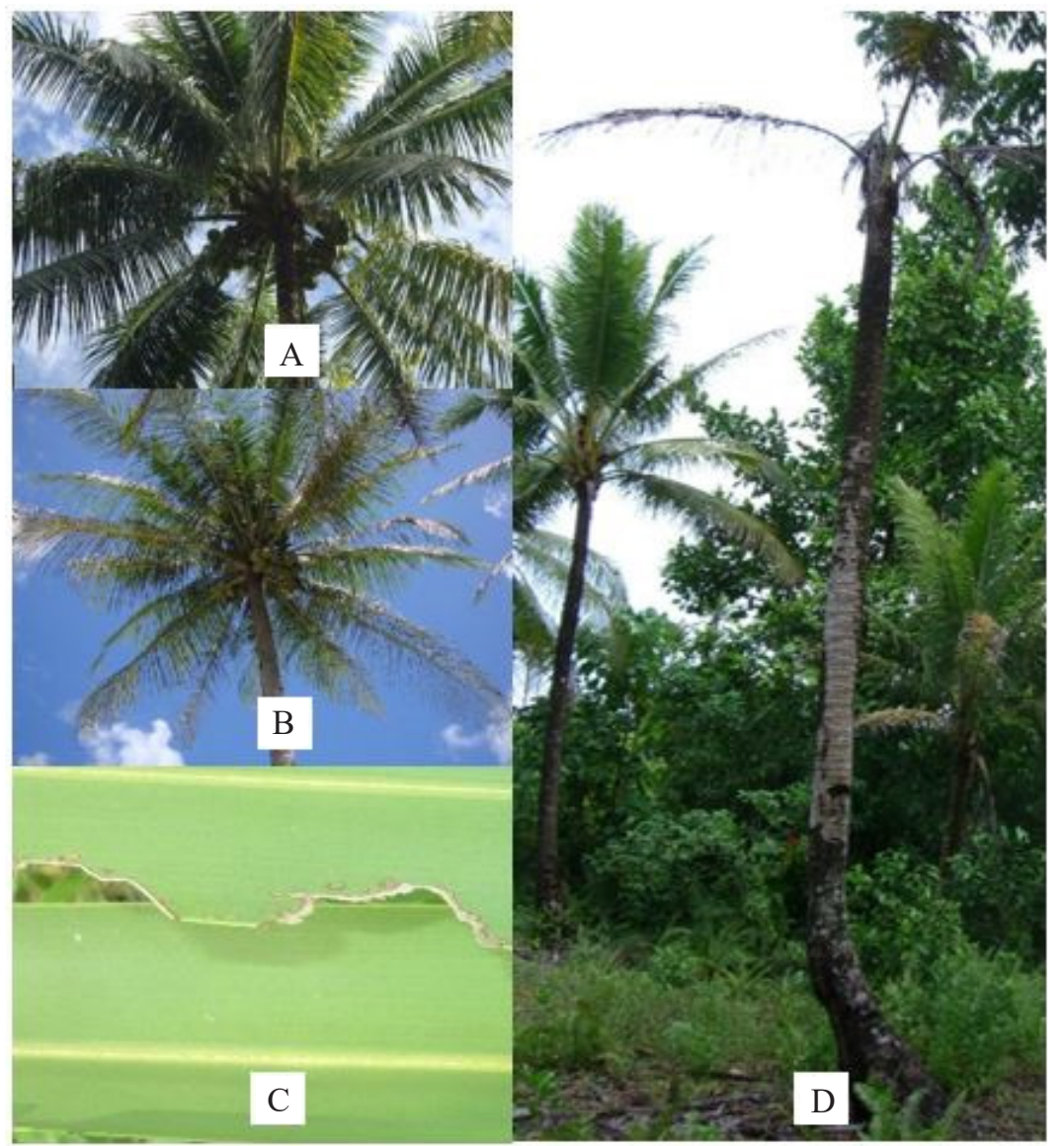

Gambar 2. Kanopi kelapa sehat dan terserang berat oleh belalang Sexava. A: pelepah daun sehat; B: pelepah daun rusak berat; C: bekas gigitan belalang Sexava pada anak daun; D: pohon kelapa mati.
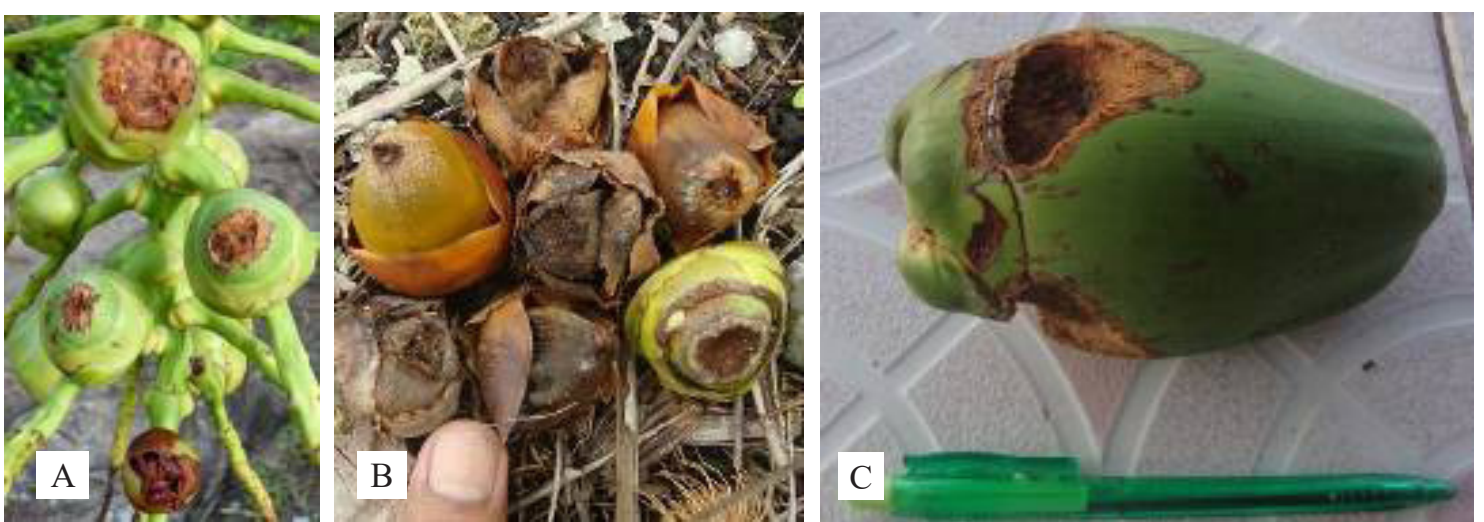

Gambar 3. Bekas serangan belalang Sexava pada bluluk dan cengkir. A: bluluk segar; B: bluluk di tanah; C: cengkir. 


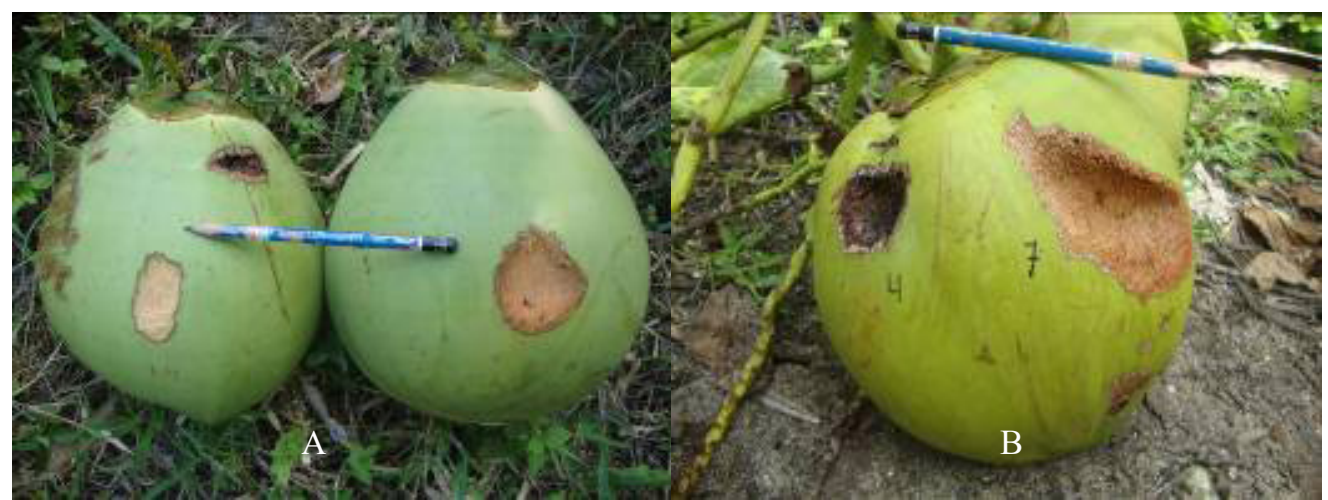

Gambar 4. Bekas serangan belalang Sexava pada degan. A: bekas serangan baru pada degan; B: bekas serangan baru dan lama pada degan.
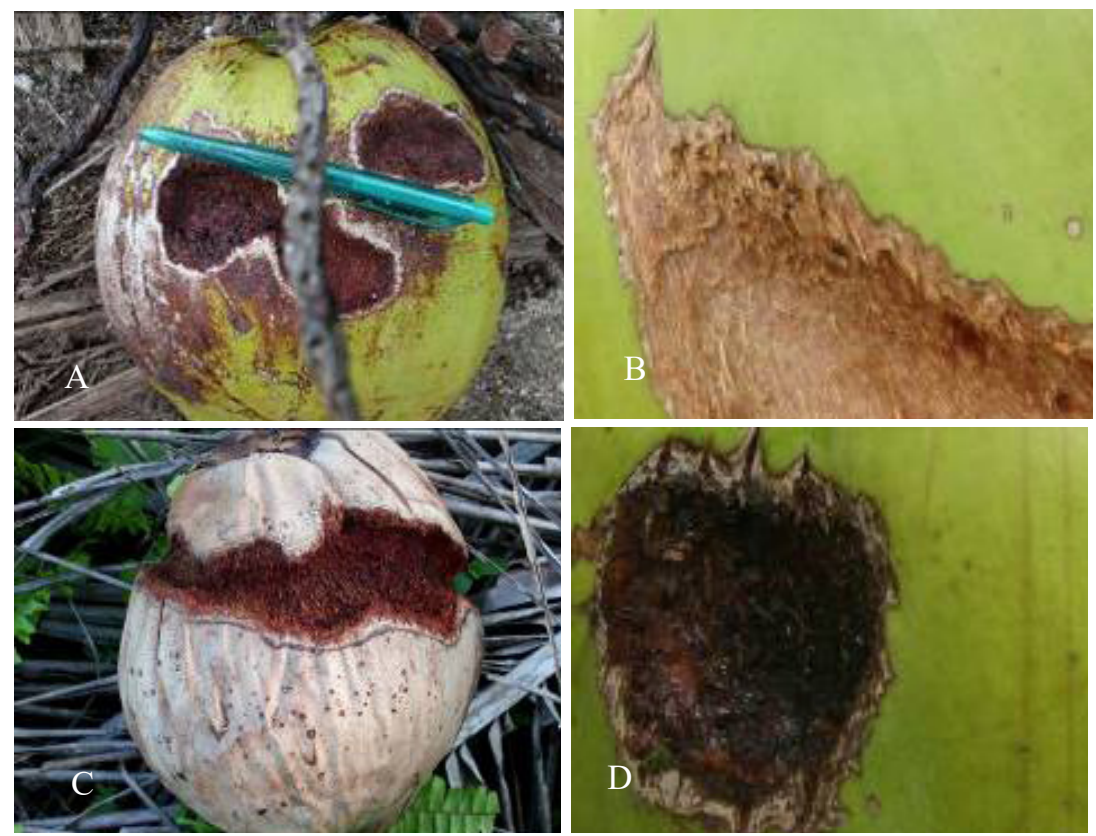

Gambar 5. Tanda serangan belalang Sexava pada kelapa tua. A: bekas serangan lama pada kelapa tua; B: clouse up serangan baru; C: bekas serangan lama pada kelapa kering; D: close up bekas serangan lama, tampak getah.

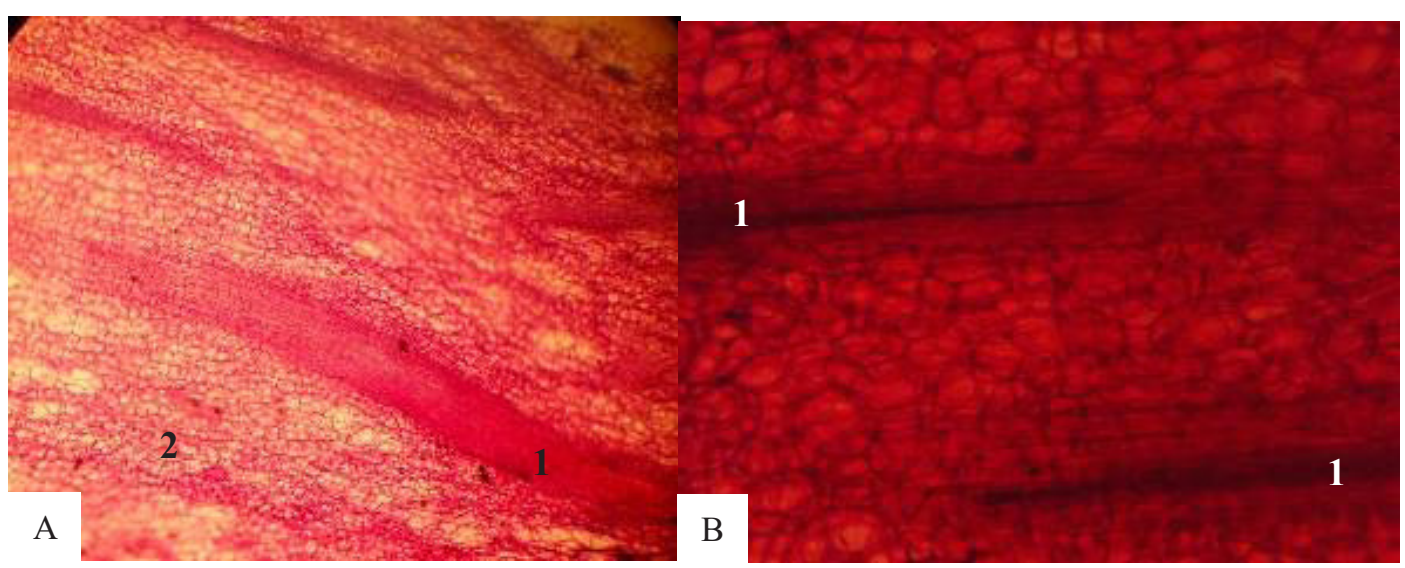

Gambar 6. Penampang jaringan bluluk. A: penampang membujur jaringan bluluk sehat (100x); B: penampang membujur jaringan bluluk sakit (100x), tampak ada penebalan pada sel penyusun berkas pengangkut. 1: sel penyusun berkas pengangkut; 2 : sel parenkim. 
Tabel 1. Kadar gula reduksi, selulosa, dan lignin, pada bluluk sehat dan bluluk rusak dimakan oleh belalang Sexava

\begin{tabular}{lccc}
\hline \multirow{2}{*}{ Sampel } & \multicolumn{3}{c}{ Kadar } \\
\cline { 2 - 4 } & Gula reduksi (\%) & Selulosa (\%) & Lignin (\%) \\
\hline Blukuk sehat (1) & 1,22 & 2,65 & 5,87 \\
Blukuk sehat (2) & 1,21 & 2,78 & 5,45 \\
\hline Rerata & 1,22 & 2,72 & 5,66 \\
\hline Bluluk rusak (1) & 1,21 & 2,86 & 4,85 \\
Bluluk rusak (2) & 1,22 & 2,83 & 4,83 \\
\hline Rerata & 1,22 & 2,85 & 4,84 \\
\hline
\end{tabular}

bakteri dan cendawan sebagai patogen belum dapat disimpulkan karena jenisnya belum berhasil diidentifikasi. Berdasarkan hasil pengamatan lapangan bahwa bluluk luka yang masih berada di pohon tidak bercendawan atau busuk maka kesimpulan awal isolat bakteri dan cendawan tersebut mengarah pada bakteri dan cendawan saprofitik.

\section{PEMBAHASAN}

Nimfa dan imago belalang Sexava menggigit dan mengunyah daun dan buah kelapa sehingga melukai bagian tanaman yang diserang. Intensitas kerusakan kanopi daun sangat berat, ditunjukkan oleh $75 \%$ lebih pelepah meranggas (Wagiman et al. 2012). Ilustrasi ini mengindikasikan daya merusak belalang Sexava yang tinggi. Sabbatoellah \& Hosang (2006) melaporkan bahwa luas daun dikonsumsi oleh belalang $S$. nubila nimfa instar I, II, III, dan IV serta imago betina dan jantan berturut-turut seluas 2,$81 ; 11,25 ; 16,06 ; 44,00$; 24,07; dan 38,67 $\mathrm{cm}^{2} /$ hari. Dampak signifikan defoliasi adalah berkurangnya leaf area index (LAI) kemudian pada gilirannya produksi buah berkurang karena berkurangnya produksi asimilat. Daun tersisa dari serangan belalang tampak hijau segar sama seperti pada kelapa sehat. Proses kerusakan daun diduga kuat secara mekanik dan tidak tampak adanya gejala kerusakan fitotoksik seperti pada serangga hama penghisap (Wagiman 2006). Pengamatan lapangan dan laporan penelitian sebelumnya menunjukkan bahwa ada pohon kelapa yang mati (Gambar 2) akibat diserang oleh hama Sexava (Zelazny \& Hosang 1988). Kelapa mati diduga karena defoliasi parah berkepanjangan dan tanpa perawatan. Pengaruh kelembaban dan suhu terhadap fisiologi tanaman kelapa telah dilaporkan oleh Rashid et al. (2015) di Banglades, kerusakan tanaman kelapa disebabkan oleh kondisi suhu rerata kurang dari $17{ }^{\circ} \mathrm{C}$ dan curah hujan $11,7 \mathrm{~cm}$.

Bagian tanaman kelapa yang dimakan belalang Sexava menentukan kehilangan hasil. Ambang ekonomi hama Sexava antara lain dapat ditentukan dengan analisis hubungan antara intensitas kerusakan dan kehilangan hasil. Zelazny \& Hosang (1988) telah mengkaji intensitas kerusakan tersebut. Pada lokasi tanpa perlakuan insektisda sistemik, rata-rata kerusakan tanaman meningkat dari $21,3 \%$ menjadi $26,5 \%$, angka kerusakan tersebut telah melampaui batas ambang kerusakan ekonomi (>20\%) (Balitka 1990). Kerusakan pelepah daun muda lebih berpengaruh terhadap pengurangan produksi dibandingkan dengan pelepah tua. Pada saat terjadi eksplosi hama ini, kerusakan parah terjadi pada daun muda. Estimasi defoliasi kelapa oleh serangga hama telah dikembangkan oleh Zelazny \& Hosang (1991).

Dampak kerusakan parah pada bluluk diduga kuat menyebabkan kerontokan prematur, apalagi kerontokan fisiologis terjadi pada bakal buah dari tandan umur 1-3 bulan. Analisis jaringan dan kimia bluluk luka dan bluluk sehat memperjelas mekanisme kerusakan bakal buah. Perbedaan sel-sel berkas pengangkut cukup jelas antara jaringan bluluk sakit dan sehat, pada bluluk sakit ada kerusakan dan penebalan sel-sel berkas pengangkut. Berkas pengangkut rusak dan penurunan kadar lignin 15\% diduga kuat mengganggu proses fisiologis bakal buah. Luka dalam dan lebar di ujung buah diduga mempercepat transpirasi sehingga akhirnya bluluk terserang mudah rontok prematur. Kerusakan pada cengkir dijumpai pada bagian kulit luar (exocarp) 
sampai sabut (mesocarp) bahkan ada yang sampai pada tempurung (endocarp) di posisi dekat pangkal buah. Luka dalam dan lebar serta lebih dari satu tempat diduga menyebabkan buah akan rontok karena kekurangan air akibat penguapan cepat atau pangkal buah membusuk jika hujan air tertampung di dalam luka. Kerusakan pada degan dan kelapa tua dijumpai pada bagian kulit luar (exocarp) sampai sabut (mesocarp) di posisi tengah buah. Luka bervariasi dari sempit dan dangkal sampai lebar dan dalam. Fakta lapangan menunjukkan bahwa buah terserang dari tandan umur 4 bulan lebih masih tumbuh dan berkembang sampai siap dipanen. Luka tersebut tampaknya tidak berpengaruh. Getah tampak keluar dari kulit luar dan sabut yang luka menunjukkan respons ketahanan kelapa terhadap luka. Bluluk luka akibat dimakan belalang Sexava diduga mudah terinfeksi oleh suatu patogen sekunder. Hasil isolasi di laboratorium menunjukkan bahwa isolat cendawan dan bakteri dari bluluk dengan luka baru diduga termasuk saprofitik sehingga dugaan adanya penyakit sekunder tidak terlalu kuat.

\section{KESIMPULAN}

Nimfa dan imago belalang Sexava memakan daun dan buah kelapa sejak bakal buah (bluluk), cengkir, kelapa muda (degan), sampai buah tua. Bakal buah yang terserang gugur, sedangkan buah kelapa muda berumur 3 bulan lebih yang terserang dapat berkembang hingga tua. Gigitan belalang Sexava pada bakal buah kelapa tidak berpengaruh signifikan terhadap kadar gula reduksi, selulosa, dan lignin. Sel penyusun jaringan pengangkut pada buah terserang tampak lebih tebal daripada yang sehat. Proses kerusakan daun dan buah kelapa akibat serangan hama belalang Sexava terjadi secara mekanik. Kerusakan karena patogen sekunder dan fitotoksik akibat gigitan belalang tersebut tidak dijumpai.

\section{UCAPAN TERIMA KASIH}

Penelitian ini didanai oleh Anggaran DIPA UGM Nomor: LPPM-UGM/671/BID.I/2012 Tanggal 5 Maret 2012. Perhargaan dan ucapan 178 terima kasih disampaikan kepada Pusat Studi Pengelolaan Sumber Daya Hayati, UGM; Balai Penelitian Kelapa dan Palma Lain Manado; Laboratorium Struktur dan Perkembangan Tumbuhan, Fakultas Biologi, UGM; Laboratorium Kimia PAU UGM; Petani Kelapa di Pulau Salibabu, serta semua pihak yang telah membantu, atas segala dukungannya.

\section{DAFTAR PUSTAKA}

Alouw VjC, Hosang MLA. 2016. Sexava nubila (Orthoptera: Tettigoniidae): Ledakan dan kerusakannya pada tanaman kelapa sawit. Buletin Palm 17:97-104. doi: https://doi. org/10.21082/bp.v17n2.2016.97-104.

Balitka. 1990. Pedoman Pengendalian Hama dan Penyakit Kelapa. Jakarta: Badan Litbang, Balitka, FAO/UNDP, Dirjenbun, Direktorat Perlintan.

Caudwell RW, Orrell I. 1997. Integrated pest management for oil palm in Papua New Guinea. Integrated Pest Management Reviews 2:17-24. doi: https://doi. org/10.1023/A:1018420211050.

DebMandal M, Mandal S. 2011. Coconut (Cocos nucifera L.: Arecaceae): In health promotion and disease prevention. Asian Pacific Journal of Tropical Medicine 4:241-247. doi: https:// doi.org/10.1016/S1995-7645(11)60078-3.

Dinas Perkebunan Propinsi Sulawesi Utara. 2008. Laporan Tahunan Serangan Hama Sexava Pada Tanaman Kelapa. Manado: Dinas Perkebunan Propinsi Sulawesi Utara.

Hosang MLA. 2005. Bioekologi hama Sexava spp. (Orthoptera: Tettigoniidae). Di dalam: Monograf Hama dan Penyakit Kelapa. hlm. 1-10. Manado: Balai Penelitian Tanaman Kelapa dan Palma Lain Manado.

Rashid MM, Hasan MS, Rahman MH, Ahmmed ANF, Khalequzzaman KM. 2015. Physiological and structural abnormalities of coconut plants (Cocos nucifera L.) at different stages of growth and plantation sites under low temperature condition in Bangladesh. The Agriculturists 13:113-119. doi: https://doi. org/10.3329/agric.v13i2.26600.

Sabbatoellah S, Hosang MLA. 2006. Kemampuan 
makan Sexava nubila Stal (Orthoptera: Tettigoniidae) pada daun kelapa. Buletin Palma 31:79-90.

Siahaya VG. 2014. Coconut plant damaged attack by Sexava nubila and Oryctes rhinoceros in Kairatu Distric, West Seram Regency. Jurnal Budi daya Pertanian 10:93-99.

Wagiman FX, Hosang MLA, Lala F. 2012. Dampak serangan hama belalang Sexava terhadap kerusakan bunga betina dan buah kelapa. Di dalam: Makalah Seminar Nasional Hasilhasil Penelitian Pertanian dan Perikanan Tahun 2012. (Yogyakarta, 5 September 2012). Yogyakarta: Fakultas Pertanian UGM.

Wagiman FX. 2006. Pengendalian Hayati Hama Kutu Perisai Kelapa dengan Predator Chilocorus politus. Yogyakarta: Gadjah Mada University Press.

Warouw J. 1981. Dinamika Populasi Sexava nubila Stal. (Orthoptera: Tettigoniidae) di Sangihe
Talaud dalam Hubungan dengan Kerusakan Tanaman Kelapa. Disertasi. Bogor: Institut Pertanian Bogor.

Yong WJWH, Ge L, Ng YF, Tan SN. 2009. The chemical composition and biological properties of coconut (Cocos nucifera L.). Molecules 14:5144-5164. doi: https://doi. org/10.3390/molecules 14125144 .

Zelazny B, Hosang MLA. 1988. Ecological studies on Sexava spp. and discussion on control with pesticides. Di dalam: UNDP/FAO Integrated Coconut Pest Control Project, Annual Report. hlm. 69-78. Manado: Balai Penelitian Kelapa. Zelazny B, Hosang MLA. 1991. Estimating defoliation of coconut palms by insect pest. Tropical Pest Management 37:63-65. doi: https://doi.org/10.1080/09670879109371538. 